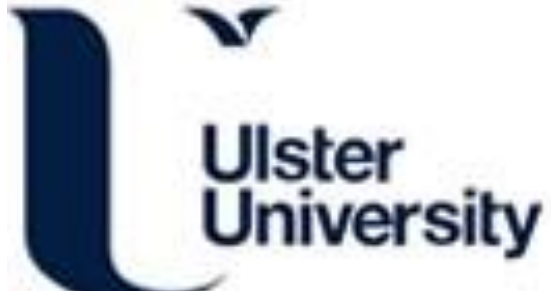

\section{Unraveling the cell-type dependent radiosensitizing effects of gold through the development of a multifunctional gold nanoparticle}

Nicol, J. R., Harrison, E., O'Neill, S. M., Dixon, D., McCarthy, H. O., \& Coulter, J. A. (2018). Unraveling the celltype dependent radiosensitizing effects of gold through the development of a multifunctional gold nanoparticle. Nanomedicine: Nanotechnology, Biology, and Medicine, 14(2), 439-449.

https://doi.org/10.1016/j.nano.2017.11.019

Link to publication record in Ulster University Research Portal

Published in:

Nanomedicine: Nanotechnology, Biology, and Medicine

Publication Status:

Published (in print/issue): 01/02/2018

DOI:

10.1016/j.nano.2017.11.019

\section{Document Version}

Author Accepted version

\section{General rights}

Copyright for the publications made accessible via Ulster University's Research Portal is retained by the author(s) and / or other copyright owners and it is a condition of accessing these publications that users recognise and abide by the legal requirements associated with these rights.

\section{Take down policy}

The Research Portal is Ulster University's institutional repository that provides access to Ulster's research outputs. Every effort has been made to ensure that content in the Research Portal does not infringe any person's rights, or applicable UK laws. If you discover content in the Research Portal that you believe breaches copyright or violates any law, please contact pure-support@ulster.ac.uk. 




\section{Unravelling the cell-type dependent radiosensitising effects of gold through the development of a multifunctional gold nanoparticle}

Nicol, J. R., Harrison, E., O'Neill, S. M., Dixon, D., McCarthy, H. O., \& Coulter, J. A. (2018). Unravelling the celltype dependent radiosensitising effects of gold through the development of a multifunctional gold nanoparticle. Nanomedicine: Nanotechnology, Biology and Medicine, 14(2), 439-449.

https://doi.org/10.1016/j.nano.2017.11.019

Published in:

Nanomedicine: Nanotechnology, Biology and Medicine

Document Version:

Peer reviewed version

Queen's University Belfast - Research Portal:

Link to publication record in Queen's University Belfast Research Portal

\section{Publisher rights}

Copyright 2017 Elsevier.

This manuscript is distributed under a Creative Commons Attribution-NonCommercial-NoDerivs License

(https://creativecommons.org/licenses/by-nc-nd/4.0/), which permits distribution and reproduction for non-commercial purposes, provided the author and source are cited.

\section{General rights}

Copyright for the publications made accessible via the Queen's University Belfast Research Portal is retained by the author(s) and / or other copyright owners and it is a condition of accessing these publications that users recognise and abide by the legal requirements associated with these rights.

Take down policy

The Research Portal is Queen's institutional repository that provides access to Queen's research output. Every effort has been made to ensure that content in the Research Portal does not infringe any person's rights, or applicable UK laws. If you discover content in the Research Portal that you believe breaches copyright or violates any law, please contact openaccess@qub.ac.uk. 
Unravelling the cell-type dependent radiosensitising effects of gold through the development of a multifunctional gold nanoparticle

James R. Nicol ${ }^{1}$, Emma Harrison ${ }^{2}$, Shannon M. O’Neill ${ }^{1}$, Dorian Dixon ${ }^{2}$, Helen O. McCarthy ${ }^{1}$, Jonathan A. Coulter ${ }^{1}$.

${ }^{1}$ School of Pharmacy, Queen's University Belfast, 97 Lisburn Road, Belfast, BT9 7AE, United Kingdom.

${ }^{2}$ School of Engineering, Ulster University, Jordanstown campus, Shore Road, Newtonabbey, BT37 0QB, United Kingdom.

Corresponding Author:

Dr. Jonathan A. Coulter

Tel: +44 (0) 2890972253

E-mail: j.coulter@qub.ac.uk

Conflict of interest: The authors report no conflict of interest

Financial support: This work was supported by funding from the EPSRC, grant number $\mathrm{EP} / \mathrm{K} 039342 / 1$.

Abstract word count: 148

Manuscript word count: 4977

References: 50

Number of figures: 7

Number of tables: 0

Number of Supplementary figures: 3 


\section{Abstract}

The radiosensitising efficacy of gold is well established, however, there remain several significant barriers to the successful clinical translation of nano-sized gold particles (AuNPs). These barriers include: retaining stability in relevant biological sera, demonstrating effectiveness at clinically relevant AuNP concentrations and identifying the biological context where significant benefit is most likely to be achieved. Herein we have developed a AuNP preparation, stress-tested to provide effective protection from salt and serum mediated agglomeration. Furthermore, the core AuNP is co-functionalised with two biologically derived peptides designed to enhance endocytosis and promote endosomal escape, thus maximising intracellular AuNP surface area. In summary, these investigations demonstrate restored AuNP internalisation using the co-functionalised preparation that generated significant radiosensitisation, in both in vitro and in vivo models, at clinically viable treatment concentrations. Furthermore, we have identified an underpinning biological mechanism in the inherent radical scavenging capacity that could be used to predict radiosensitising efficacy.

Keywords: Gold nanoparticles, endocytosis, radiosensitisation, reactive oxygen species, DNA damage
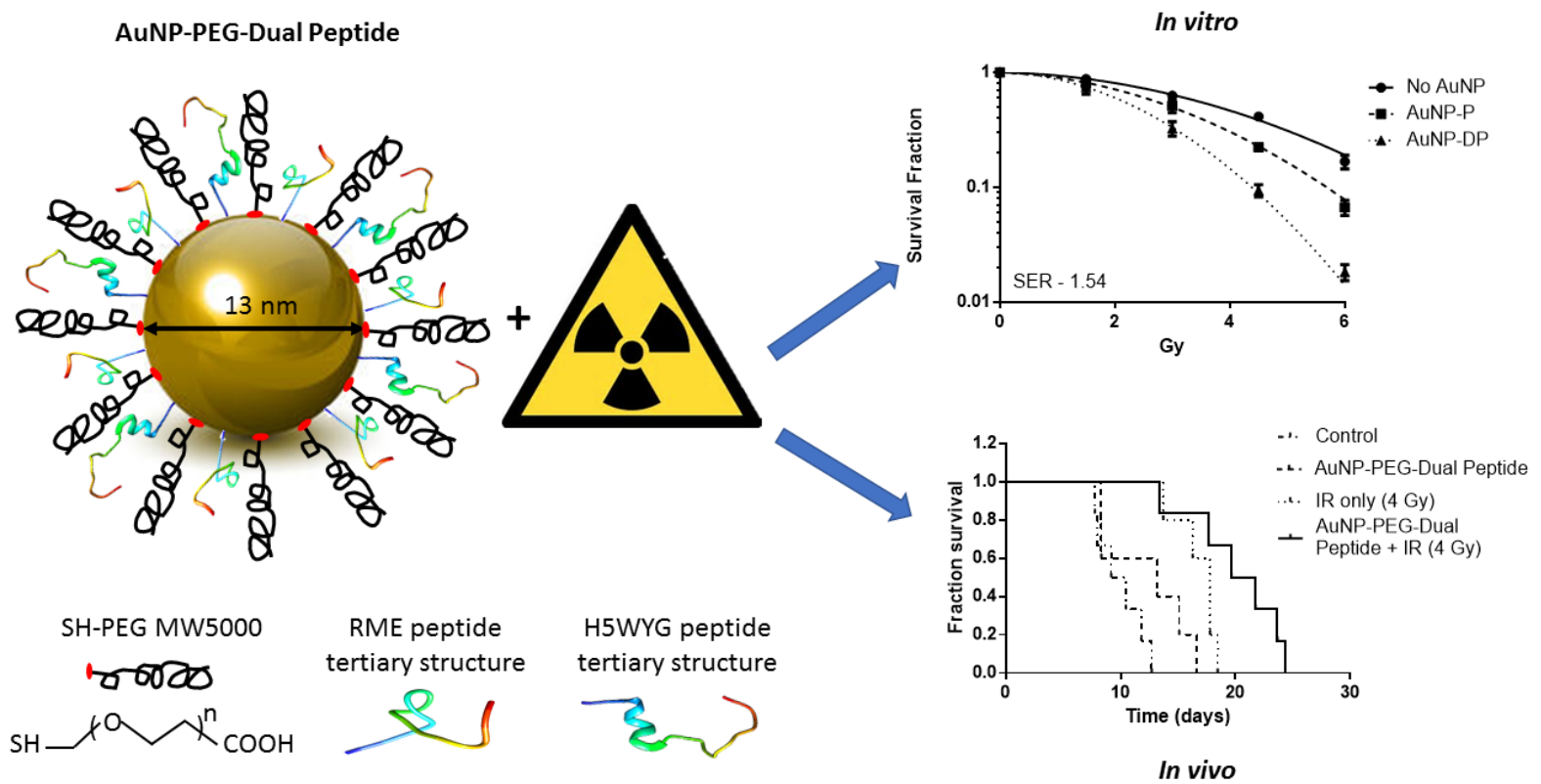


\section{Introduction}

Gold nanoparticles (AuNPs) are proven radiosensitisers at kilovoltage (keV) and megavoltage (MV) photon energies, an effect attributed, in part, to the high mass absorption coefficient of gold.(1-3) To date, most studies have focused on the impact of nanoparticle size, shape, charge and elasticity on internalisation efficacy, with several authors indicating $50 \mathrm{~nm}$ AuNPs are most avidly endocytosed.(4-6) Endocytosis of AuNPs exceeding $10 \mathrm{~nm}$ predominantly occurs via the endosomal-lysosomal degradation pathway, while direct pinocytosis dominates for sub 10 nm particles.(4,7) Achieving sufficient target cell AuNP uptake represents a major barrier to clinical translation. With this in mind we have developed a novel multi-functional AuNP, designed to promote intracellular uptake and overcome endosomal entrapment, thereby improving the radiosensitising capability. $(4,8)$ To date, the majority of radiosensitising AuNP studies rely on treatment up to $1 \% \mathrm{wt} / \mathrm{wt}$ AuNP/tumour.(9) However, the practical implications of up-scaling to these concentrations for clinical use would prove prohibitive on a cost and potentially toxicity basis.(10) Furthermore, 'as-synthesized' AuNPs aggregate at physiological conditions, requiring the addition of stabilizing moieties. Polyethylene glycol (PEG) is the most widely studied due to existing regulatory approval (MHRA and EMA) and a proven ability to increase systemic circulation time. This stabilising effect is possible as PEG limits nanoparticle opsonisation through the inhibition of non-specific absorption.(11) Despite these obvious advantages, PEG also severely hinders internalization, an effect referred to as the "PEG dilemma."(12) No optimal PEG chain length has been definitively established, but $\leq 5000 \mathrm{MW}$ PEG is thought to provide the required stability while minimising the negative impact on endocytosis.(13)

Herein, AuNPs were synthesised and co-functionalized with 5000 MW PEG, conferring stability and improved in vivo circulation times. Furthermore, synthetic derivatives of two natural peptides were used to overcome biological barriers.(14) The peptide RME derived from viral origins, contains a string of cationic lysine residues that promote internalization. Furthermore, the free thiol group within the $\mathrm{N}$-terminal cysteine residue permits robust chemisorption (enthalpy $\sim 126 \mathrm{~kJ} / \mathrm{mol}$ ) of the RME peptide to the AuNP surface. $(15,16) \mathrm{A}$ second peptide H5WYG remains unprotonated at physiological $\mathrm{pH}$, but undergoes profound conformational restructuring due to histidyl protonation under mildly acidic conditions found within the endosome.(17) This remodeling effect is further enhanced by the presence of a tryptophan-histidine bridge (WH) that confers strong alpha-helicity capable of destabilizing the endosomal membrane in a process known as the proton sponge effect. $(18,19)$ Combining 
these functional groups, we aimed to develop a AuNP capable of conferring significant radiation enhancement at a clinically relevant concentration.

Breast cancer was chosen as an exemplar tumour model based on the results of the EORTC trial and the recommendations of the Early Breast Cancer Trialists' Collaborative Group (EBCTCG).(20,21) The EORTC trial assessed the clinical benefit of a radiation boost (16 Gy) following conventional breast conserving therapy plus radiotherapy (50 Gy).(21) The results indicate that increasing the total administered dose by $30 \%$, results in $39.2 \%$ reduction in the 10-year recurrence rate, significantly reducing the requirement for salvage mastectomies. While encouraging, patients receiving the radiotherapy boost had a 2.6 fold greater risk of developing severe fibrosis and an elevated risk of ischemic heart disease, particularly for patients with cancer of the left breast. Darby et al (2013) reported that the mean dose to the heart was 6.6 Gy for women with tumours in the left breast, and that with each subsequent 1 Gy increase to the heart the risk of a major coronary event increased by 7.4\%.(22) In this context AuNPs hold real potential, delivering increased radiosensitivity, while limiting physical radiation dose delivered. Further evidence for this was recently presented in vivo where breast tumours doped with $0.5 \mathrm{mg}$ AuNP generated radiation dose enhancement equivalent to three doses of cisplatin ( $\mathrm{IC}_{25}-4 \mathrm{mg} / \mathrm{kg}$ ) without inducing intrinsic toxicity.(23) While our study focused on breast cancer, most tumours routinely treated with IR (ionising radiation) could potentially benefit, with AuNP radiosensitisation previously demonstrated in prostate, glioma and head and neck cancers.(24-26) Herein we provide a robust characterisation of AuNP synthesis and physical properties, as well as comprehensive assessment of stability and biological efficacy in vitro and in vivo including an insight into key radiosensitising mechanisms.

\section{Methods}

\section{Materials}

Chloroauric acid $\left(\mathrm{HAuCl}_{4} \cdot 3 \mathrm{H}_{2} \mathrm{O}\right)$, PEG-SH (5000 MW) and sodium citrate were obtained from Sigma Aldrich (UK). The 0.01 wt.\% chlorauric acid and 1 wt.\% sodium citrate solutions were prepared using distilled water. RME peptide (sequence CKKKKKKSEDEYPYVPN) and H5WYG peptide (sequence GCGLFHAIAHFIHGGWHGHHGWYG) were purchased from BIOMATIK (USA). Peptides were synthesised to $>99 \%$ purity, lyophilized in acetate salt with trifluoracetic acid constituting $<1 \%$. 


\section{Synthesis and Functionalization of gold nanoparticles}

The Turkevitch/Frens AuNP synthesis method has been widely employed since the 1950's and a schematic is available in Zhoa et al.(27,28) Briefly, $13 \pm 2.15 \mathrm{~nm}$ (Supplementary Figure 1) citrate capped nanoparticles (AuNP-C) were produced by reducing $400 \mathrm{ml}$ of boiling $0.01 \mathrm{wt} . \%$ chloroauric acid using $9 \mathrm{ml}$ of $1 \mathrm{wt} . \%$ sodium citrate solution, as described in our previous publication.(29) To prepare 50\% PEG capped AuNPs (AuNP-P), $10.68 \mu \mathrm{g} / \mathrm{ml}$ 5000MW PEGSH was dissolved in $1 \mathrm{ml}$ distilled water and added to the citrate reduced AuNPs.(30) The colloid/PEG solution was vigorously mixed for $8 \mathrm{~h}$ at room temperature allowing PEG/citrate exchange. Excess unconjugated PEG was removed by centrifugation (12000 RCF for $90 \mathrm{~min}$ ). Single peptide preparations (50\% PEG / 50\% peptide) functionalised with RME (AuNP-R) or H5WYG (AuNP-H5) were produced by adding 4.4 and $7.86 \mu \mathrm{g} / \mathrm{ml}$ of free peptide respectively. Finally the co-functionalised preparation (termed dual peptide, AuNP-DP) was produced by adding $2.23 \mu \mathrm{g} / \mathrm{ml}$ of free RME peptide (dissolved in $1 \mathrm{ml}$ of distilled water) and $3.93 \mu \mathrm{g} / \mathrm{ml}$ of H5WYG peptide to AuNP-P, mixed for $8 \mathrm{~h}$, then washed to remove excess unconjugated peptide.

\section{AuNP characterization}

Nanoparticle size, charge and polydispersity were determined by dynamic light scattering (DLS) using a Malvern Nano Zetasizer ZS Series. Fourier transform infrared spectroscopy (FTIR) spectra were recorded in the range of $400-4000 \mathrm{~cm}^{-1}$ at a resolution of $4 \mathrm{~cm}^{-1}$ on a Varian 640-IR FTIR spectrometer. UV-Visible spectra were recorded using a Perkin Elmer Lambda 35 in the range $400-600 \mathrm{~nm}$ at $0.1 \mathrm{~nm}$ increments. Stress testing AuNP stability in high ionic solutions $(1 \mathrm{M} \mathrm{NaCl})$ was conducted by UV/Vis measurement of the characteristic plasmon peak over $24 \mathrm{~h}$. Serum stably was established using DLS following a $24 \mathrm{~h}$ incubation medium containing $10 \%$ or $40 \%$ foetal calf serum.

\section{Cell culture and AuNP delivery}

MDA-MB-231 and MCF-7 human breast cancer cell lines were cultured in Dulbecco's modified eagle's medium (DMEM) supplemented with 10\% fetal bovine serum (FBS). Normal breast epithelial cell line MCF-10A were cultured in DMEM/F-12 supplemented with 5\% horse serum, $20 \mathrm{ng} / \mathrm{ml}$ epidermal growth factor, $0.5 \mathrm{mg} / \mathrm{ml}$ hydrocortisone, $100 \mathrm{ng} / \mathrm{ml}$ cholera toxin and $10 \mu \mathrm{g} / \mathrm{ml}$ insulin. Cells were maintained at $37^{\circ} \mathrm{C}, 95 \%$ air $/ 5 \% \mathrm{CO}_{2}$ and sub-cultured every 
3-4 days to maintain exponential growth. Unless specifically stated, all AuNP treatments were performed at $25 \mu \mathrm{g} / \mathrm{ml}$ for $24 \mathrm{~h}$.

Inductively coupled plasma atomic absorption spectroscopy (ICP-AAS)

AuNP uptake was quantified using ICP-AAS as previously described.(24) Data is normalized to AuNP-P, to represent the fold-increase in nanoparticle internalisation following peptide conjugation.

\section{In Vitro Cytotoxicity}

AuNP induced toxicity was assessed using both the WST-1 assay and xCELLigence platform. Briefly, $2 \times 10^{4}$ AuNP treated $(25 \mu \mathrm{g} / \mathrm{ml})$ cells were washed twice with PBS prior to the addition of $10 \%$ WST-1 for $4 \mathrm{~h}$. Cell viability was determined by changes in absorbance at $\Lambda 440 \mathrm{~nm}$ relative to untreated controls. Concentration dependent toxicity was assessed using the xCELLigence platform as previously described (ACEA, US). (31)

\section{CytoViva analysis of cells with internalized AuNP-DP}

Cytoviva enhanced darkfield/hyperspectral microscopy permits the optical observation and spectral confirmation of nanoparticles, where AuNPs appear bright due to their high scattering cross-section. Hyperspectral imaging permits capture and recording of unique reflectance spectra (compared against untreated controls) on a pixel-by-pixel basis, providing confirmation of internalisation and intracellular localization. $3 \times 10^{4}$ cells were seeded into a 4 -well chamber slide (Corning-US), treated with AuNPs, then fixed with 10\% Formalin.

\section{AuNP induced radiosensitivity}

Survival fractions were generated by clonogenic assay, as previously described.(24) Samples were irradiated with doses between 0-6 Gy using a $160 \mathrm{kVp}$ X-ray cabinet source. Sensitiser enhancement ratio (SER) was calculated by fitting the surviving fraction data to the linear quadratic model, establishing the area under curve (mean inactivation dose - MID) at a surviving fraction of 0.1 , then dividing the MID of AuNP treated cells against corresponding controls.

\section{DNA Damage Analysis}

$7.5 \times 10^{4}$ cells were seeded, left to adhere, then treated with AuNPs for $24 \mathrm{~h}$. AuNP treated cells were irradiated ( $1 \mathrm{~Gy}$ ), then returned to the incubator for $4 \mathrm{~h}$ allowing partial DNA repair. Cells 
were fixed and permeabilised using $100 \%$ methanol at $-20^{\circ} \mathrm{C}$, then blocked using $2 \% \mathrm{FBS}$ in PBS at room temperature. Primary H2aX (1:300 in PBS) and secondary antibody (1:400 in PBS) incubations were performed at room temperature prior to mounting using VECTASHIELD plus DAPI at $0.75 \mu \mathrm{g} / \mathrm{ml}$. H2aX foci for 100 cells per condition were scored.

\section{Radiation and AuNP induced Reactive Oxygen Species (ROS)}

In the presence of ROS 2',7'-dichlorofluorescin diacetate (DCFDA) is oxidised to fluorescent 2', 7'-dichlorofluorescein (DCF). $1.5 \times 10^{4}$ cells were seeded and allowed to adhere for $24 \mathrm{~h}$. Medium containing $5 \mu \mathrm{M}$ DCFDA was added for $40 \mathrm{~min}$ allowing internalisation, and replaced with fresh media. Cells were irradiated with a 2 Gy dose and ROS levels measured using a fluorescent plate reader at 495/529 $\mathrm{nm}$. To detect ROS levels following AuNP and IR treatment, cells were first pre-treated with AuNP for $2 \mathrm{~h}$, during the last 40 min $5 \mu \mathrm{M}$ DCFDA was added.

\section{Western Blotting for SOD2}

Whole cell lysates were collected by adding $150 \mu \mathrm{l}$ Laemmli buffer (Sigma) to adherent cells following AuNP and/or 2 Gy IR treatments. Western blotting was then performed as previously described.(32) Primary antibodies were used at 1:1000 (anti-SOD2 and anti- $\beta$-actin, ThermoFisher Scientific) in $5 \%$ blocking buffer at $4{ }^{\circ} \mathrm{C}$. Secondary antibody was used at 1:5000 in 1\% blocking buffer for $1 \mathrm{~h}$. Densitometry analysis was performed using Image J.

In vivo tumour growth delay model

All animal experiments were carried out in accordance with QUB institutional regulations and the Animal (Scientific Procedures) Act of 1986, conforming to the current United Kingdom Co-ordinating Committee on Cancer Research (UKCCCR) guidelines.

BALB/C SCID mice (6-8 week-old) were used to develop a sub-cutaneous (s.c.) MDA-MB231 tumour xenograft model. Mice were anesthetized using isoflurance $\left(3 \%\right.$ in $\left.\mathrm{O}_{2}\right)$ and $1.5 \times 10^{6}$ MDA-MB-231 cells injected into the rear dorsum. Tumours were grown to approximately 100 $\mathrm{mm}^{3}$, at which point animals were randomly assigned to one of four experimental groups; untreated, AuNP-DP only, IR only (4 Gy), AuNP-DP + 4 Gy. AuNP-DP (6 mg/kg) was delivered by direct intra-tumoural injection equating to $150 \mu \mathrm{g}$ Au per $25 \mathrm{~g}$ animal. In vivo radiation treatments were delivered using a small animal radiation research platform (SARRP - Xstrahl). Tumours were imaged by CT and treated using two parallel beams delivering 4 Gy 
$225 \mathrm{kVp}$ x-rays. Upon recruitment to the study animal weights and tumour volume were recorded three times weekly. Tumour volume was measured in three orthogonal dimensions. Experimental endpoints for individual animals were defined by tumor volume exceeding 400 $\mathrm{mm}^{3}$ or animals losing more than $10 \%$ of their maximum body weight.

\section{Results}

\section{AuNP Characterization}

DLS was used to establish size and surface charge (Figures 1A\&B) characteristics. Following PEG conjugation hydrodynamic size increases to $28.7 \mathrm{~nm} \pm 0.89 \mathrm{~nm}$, towards the optimal range for uptake.(5) Nanoparticle size increased slightly (AuNP-DP: $36.6 \mathrm{~nm} \pm 3.07$ ) following peptide conjugation with the AuNP-H5 preparation exhibiting the most significant increase to $45.9 \pm 0.92 \mathrm{~nm}$. Comparable sizing between nanoparticle preparations indicate a mixed monolayer configuration between PEG and the bioactive peptides.(29) Citrate AuNPs possess a strong negative charge at $-31.5 \mathrm{mV}$, which reduces to $-7.2 \mathrm{mV}$ after PEG conjugation. Both the RME and H5WYG peptides alone further reduce the negative surface charge, remaining anionic. However, the combination of both peptides (AuNP-DP) yields an overall cationic particle with a net charge of $6.5 \mathrm{mV}$.

The position of surface plasmon peak shifts from $518 \mathrm{~nm}$ for the AuNP-C, to 521.5 for AuNP$\mathrm{P}$ and further to $254.6 \mathrm{~nm}$ after conjunction with both peptides (Figure 1C). This measured upshift in peak position of 2-3 nm is consistent with AuNP functionalization.(33) Samples functionalized with PEG together with only the RME or H5WYG peptides displayed $\kappa_{\max }$ positions of 524 and $524.3 \mathrm{~nm}$ respectively.

The FTIR Spectra of washed and dried, AuNP-P, RME and H5 peptides alone and AuNP-DP are shown in Figure 1D. A comparison of the FTIR spectra of AuNPs before and after PEGylation is detailed in our previous publications. $(29,30)$ The presence of PEG on the AuNPP sample is confirmed by a peak at $1,106 \mathrm{~cm}^{-1}$ (C-O-C stretching) and narrowing of the $\mathrm{C}-\mathrm{H}_{2}$ peak $\left(2,850 \mathrm{~cm}^{-1}\right)$ indicative of ethylene glycol moieties $(29,30,34,35)$

Peptide groups elicit characteristic amide bands in several regions. Characteristic Amide A resulting from N-H stretching vibrations at $\sim 3500 \mathrm{~cm}^{-1}$ are evident on the spectra of the free H5WYG peptide and on the AuNP-DP sample, indicating the presence of H5WYG on the surface. A small broad peak is also visible in the spectra of the RME sample in this region. The Amide band I resonates between $1600-1700 \mathrm{~cm}^{-1}$, is associated with $\mathrm{C}=\mathrm{O}$ stretching and is sensitive to conformation.(36) Amide I peaks are observed in the H5WYG and RME spectra 
at 1666 and $1680 \mathrm{~cm}^{-1}$ respectively. The series of features in the $1690-1620$ region on the dual peptide samples is consistent with the presence of the peptides. The spectra of the AuNP sample capped only with PEG shows no activity in this region. The presence of the RME peptide on the dual peptide sample is further supported by peaks at 982 and $850 \mathrm{~cm}^{-1}(\mathrm{~N}-\mathrm{H}$ wagging), which are visible on the spectra of both the RME peptide and dual peptide samples.

The FTIR data combined with the UV-Vis and Zeta measurements strongly supports the successful conjunction of both peptides to the surface. This is further reinforced by Figure 3A illustrating superior internalization using AuNP-DP.

UV-vis was also used to demonstrate nanoparticle stability in strong ionic fluids (1 M NaCL) (Figure 2A). Importantly, both AuNP-P and AuNP-DP show no change in their UV-spectral profile over time, indicating stability in excess of physiologically relevant concentrations. In contrast AuNP-C shows a rapid reduction in absorbance almost immediately, indicative of irreversible agglomeration. Serum stability (Figure 2B) was assessed by changes in particle size. DLS measurements indicate significant $(\mathrm{p}<0.001)$ particle agglomeration of AuNP-C in medium containing $10 \%$ serum, an effect totally abrogated following PEG conjugation. Indeed, protection against non-specific protein absorption was also conferred peptide conjugated variants including AuNP-DP.

\section{AuNP cellular uptake}

While PEG provides effective protection against agglomeration, it is widely acknowledged to impair cell internalisation.(37) Figure 3A represents ICP-AAS data, used to quantify intracellular Au per cell following AuNP treatment. In all cells, intracellular AuNP levels failed to exceed $0.3 \mathrm{pg} \mathrm{Au/cell} \mathrm{following} \mathrm{AuNP-P} \mathrm{treatment.} \mathrm{Conjugation} \mathrm{of} \mathrm{either} \mathrm{the} \mathrm{RME} \mathrm{or}$ H5WYG improved AuNP internalisation; however, nanoparticle uptake was maximally restored following conjugation with both peptides, yielding an 12.08, 16.3 and 8.3 fold increase over AuNP-P in MCF-10A, MDA-MB-231 and MCF-7 cells respectively, corresponding to $4.14 \mathrm{pg} / \mathrm{cell}$ in MDA-MB-231 cells.

\section{AuNP Induced Cytotoxicity}

WST-1 assay (Figure 3B) was used to assess the short-term impact of AuNP treatment on viability. At $25 \mu \mathrm{g} / \mathrm{mL}$, no significant cytotoxicity was observed from any AuNP preparations (Supplementary Figure 2 AuNP-R and AuNP-H5). Using xCELLigence, concentration dependent cytotoxicity of AuNP-DP was assessed over $72 \mathrm{~h}$ (Figure 3C and 3D). 
Biocompatibility was observed up to $300 \mu \mathrm{g} / \mathrm{mL}$, after which higher exposure concentrations significantly reduced viability.

\section{CytoViva Imaging}

Intracellular distribution was investigated using enhanced darkfield and hyperspectral imaging (HSI) (Figure 4). Enhanced darkfield images (Panels A,C,E) of high intensity bright areas potentially represents AuNPs, absent from control samples. Clusters are located within the perinuclear region of the cell and more diffusely distributed throughout the cytoplasm. Using pixelby-pixel hyperspectral filtering against untreated controls, false positives are eliminated, producing a spectral map confirming the intracellular locality of AuNP-DP (mapped in red). Hyperspectral images generate maximum intensity projected images which compress z-plane data, therefore AuNPs which appear to co-localise with the cell nucleus are likely cytoplasmic, located above or below the nucleus.

\section{In vitro AuNP Induced Radiosensitivity}

Colony forming assays were used to determine the radiosensitising potential of the AuNP preparations (Figure 5 A-C). In normal MCF-10A cells, no radiation dose enhancement was observed with AuNP-P, and a modest, but significant ( $\mathrm{p}=0.003$ ) SER of 1.19 recorded using the fully functionalised AuNP-DP. Conversely, highly significant sensitisation was observed in MDA-MB-231 cells with AuNP-P and AuNP-DP generating average SERs of 1.25 ( $\mathrm{p}=0.01$ ) and $1.54(\mathrm{p}<0.001)$ respectively. Importantly, radiosensitisation was significantly increased at higher radiation doses, where a 4 Gy SER of 3.19 was obtained. In MCF-7 cells, no significant radiosensitisation was observed using the MID which incorporates data from the full survival curve. However, like the MDA-MB-231 cell, AuNP-DP significantly sensitised MCF-7 cells to higher dose fractions producing a SER of 2.57 at $6 \mathrm{~Gy}$. Similar radiosensitisation survival effects, although less pronounced at higher radiation doses, were obtained using the single peptide (AuNP-R and AuNP-H5) preparations (Supplementary Figure 3A-C).

\section{Underpinning mechanisms}

As AuNP-DP resulted in maximum nanoparticle internalisation, and the greatest radiation dose modifying effects, subsequent mechanistic and in vivo studies focused on the AuNP-DP formulation. To establish if AuNP-DP radiosensitisation is due to elevated DNA double strand damage (DSB), $\gamma-\mathrm{H} 2 \mathrm{aX}$ foci were quantified (Figure 6A). In both cancer cell lines, incorporation of AuNP-DP significantly $(\mathrm{p}<0.01)$ increased DNA damage yields by 1.7 fold 
over radiation alone. Interestingly, despite greater AuNP internalisation AuNP-C induced less DNA DSB, producing a 1.2 and 1.4 fold increase in DNA lesions in MDA-MB-231 and MCF7 cells respectively.

DCFDA, a fluorescent dye was used to measure AuNP stimulated ROS following radiation treatment. Unsurprisingly, radiation alone (2 Gy) elevated ROS levels in both MDA-MB-231 and MCF-7 cells (Figure 6B and 6C). However, the extent of the response markedly differed between cell lines. MDA-MB-231 saw a rapid spike in ROS yields (5.4 fold) within 30 min, while the response was less pronounced (2.4 fold) in MCF-7 cells. A similar response was observed in cells pre-treated with AuNP-DP prior to radiation treatment. ROS experiments were expanded to assess both the endogenous and treatment induced levels of key ROS scavenging proteins including catalase, glutathione and superoxide disumatase (SOD-2). Basal and treatment induced expression of catalase and glutathione remained unchanged between both MDA-MB-231 and MCF-7 cells, however, significant differences in the expression of SOD-2 were observed (Figure 6 D-F). Normalised against MDA-MB-231 cells, MCF-7 have on average 2.45 fold high basal expression of SOD-2. However, following AuNP treatment SOD-2 expression levels were significantly (AuNP-DP $-\mathrm{p}<0.01$ ) increased in MDA-MB-231 cells. No AuNP related upregulation in SOD-2 was observed in MCF-7 cells where the basal level expression was already high. To determine the timing of this response, samples from MDA-MB-231 cells were collected at various time points over a $24 \mathrm{~h}$ period (Figure $6 \mathrm{G}-\mathrm{I}$ ). Expression levels of SOD-2 following AuNP-DP treatment gradually increased from $4 \mathrm{~h}$ post treatment, to a maximum 4.6 fold $(\mathrm{p}<0.01)$ increase $24 \mathrm{~h}$ post exposure (Figure $6 \mathrm{H})$, with a similar response observed in irradiated cells doped with AuNP-DP (Figure 6I).

\section{Xenograft tumour delay model}

An MDA-MB-231 xenograft tumour model was used to assess the in vivo radiosensitising ability of AuNP-DP (Figure 7 A-D). This tumour model was selected due to the underlying biology highlighted in figures 4 and 5, which indicate a likely benefit from including AuNPs. Figure 7A represents the mean animal weight per treatment group. Despite slight daily fluctuations, no animal dropped below the $10 \%$ threshold, indicating minimal treatment toxicity. Once recruited, untreated control tumours reached the experimental endpoint in just 9.8 days (Figure 7B). Direct inject of AuNP-DP alone had no impact on tumour growth. Analysis of the mean tumour growth data indicate that while there was a significant difference between control and both IR only $(\mathrm{p}<0.05)$ and AuNP-DP + IR $(\mathrm{p}<0.001)$ treated animals, no significant difference between IR only and AuNP-DP +IR was observed. Similarly, Kaplan- 
Meier survival analysis supported this finding, with a trend $(\mathrm{p}=0.081)$ towards increased survival, evidenced by a separation of the IR and AuNP-DP + IR curves (Figure 7C). Analysis of tumour growth to $300 \mathrm{~mm}^{3}$ reveals a different picture (Figure 7D). Unsurprisingly, IR significantly $(\mathrm{p}<0.05)$ delayed tumour growth by 3.39 days compared to untreated controls, however, in this instance AuNP-DP in combination with IR highly significantly $(\mathrm{p}<0.001)$ impaired tumour progression by 6.7 days relative to animals receiving 4 Gy only (Figure 7D).

\section{Discussion}

While the biocompatibility, tunable surface chemistry and therapeutic potential of AuNPs are well established; the number of multi-functional ( $>2$ moieties) therapeutic particles remains low. $(4,38)$ Physical AuNP characterisation provides evidence of successful conjugation (Figure 1). AuNP-DP size was measured as $\sim 40 \mathrm{~nm}$, close to the optimal size range for clathrinmediated endocytosis.(5,39) An important benefit of PEG is increased nanoparticle homogeneity and stability, of which polydispersity index (PDI) is a direct measure. AuNP-P and peptide conjugated derivatives had low PDI measurements $(0.28-0.35)$, indicative of a stable colloid.(40) PEG also affords protection against ionic and serum mediated agglomeration (Figure 2 A\&B).(41) Despite the obvious advantage of incorporating PEG, stealth molecules negatively affect cell interaction, attributed to steric hindrance.(42) This is demonstrated with the near abolition of intracellular Au using AuNP-P. RME and H5WYG peptides were grafted in an attempt to restore AuNP uptake, while retaining the stabilizing effect from PEG. The net positive charge conferred by the six-lysine residues of RME peptide promotes internalisation through non-specific electrostatic interaction with phospholipid cell membranes, enhancing uptake up to 17-fold over AuNP-P. This data was further supported by evidence of intense peri-nuclear AuNP-DP accumulation using hyperspectral imaging (Figure 4). AuNP-DP $(+6.5 \mathrm{mV})$ exhibited good biocompatibility producing little to no reduction in viability in MCF-10A and MCF-7 cells, using concentrations $<300 \mu \mathrm{g} / \mathrm{ml}$.

In general, AuNP radiosensitisation studies correlate higher intracellular Au levels with greater radiosensitisation.(43) However, despite comparable AuNP-DP internalisation minimal radiosensitisation was observed in MCF-7 and MCF-10A cells until higher (>4 Gy) radiation doses. This suggests that a positive correlation between intracellular Au and radiosensitisation represents an overly simplistic view of the underlying mechanisms. Subsequent functional assays sought to establish this through probing mechanistic and cell line variations. Of further interest is the effect of AuNP-DP on the $\alpha / \beta$ ratio; the dose that represents an equal contribution towards cell death from both direct DNA damage $(\alpha)$ and indirect damage $(\beta)$. Clinical studies 
indicate that many breast cancers could benefit from hypofractioned treatment plans due to its relatively low $\alpha / \beta$ ratio estimated at $3.8 \mathrm{~Gy}$.(44) Importantly, AuNP-DP reduces the $\alpha / \beta$ ratio of MDA-MB-231 and MCF-7 cells by 2.5 and 6.1 fold respectively, implying that AuNP-DP enhances cell death primarily via indirect, biologically mediated mechanisms.

Non-resolved DNA double strand break damage is the main cause of radiation-induced death. The recruitment and phosphorylation of DNA damage repair protein histone H2XA acts as a marker of DNA DSB lesions.(45) Four hours post irradiation (1 Gy), cells treated +/- AuNPDP were scored for DSB lesions, permitting non-complex lesion repair.(46) Consistantly AuNP-DP treated cells yield more unresolved $\gamma \mathrm{H} 2 \mathrm{aX}$ foci compared to IR only and AuNP-C. Citrate capped AuNPs are avidly endocytosed, more efficiently that any PEG modified preparation, however, persistent DSBs are lower than recorded with AuNP-DP treated cells. This effect is attributed to the H5WYG peptide, which promotes endosomal escape.(47) McMahon et al (2011) modelled nanoscale secondary electron deposition following AuNP ionisation.(48) Internal nanoparticle ionisation events lack sufficient penetrance to confer Auger mediated effects, while surface ionisations deposit high doses in very close proximity to the nanoparticle $(\sim 10 \mathrm{~nm})$. It was hypothesised that the combined endosomal escape and PEG stabilising properties of AuNP-DP increase the internal AuNP surface area, driving interactions with cell cytoplasmic organelles such as the mitochondria, inducing redox related stress, and thus enhancing nanoparticle efficacy. To test this hypothesis, DCFDA was used to measure AuNP induced ROS, with expression levels of key ROS scavenging proteins also quantified. Both MDA-MB-231 and MCF-7 cells saw a time dependent increase in ROS levels post exposure, with the magnitude of effect greatest in MDA-MB-231 cells. SOD-2 basal levels were variable, with MCF-7 cells expressing higher initial levels. Interestingly, both AuNP and radiation treatment promoted SOD-2 expression in MDA-MB-231 cells. The low basal levels of SOD-2 in MDA-MB-231 cells renders them sensitive to the effects of elevated superoxide. Assessing SOD-2 expression levels over $24 \mathrm{~h}$ revealed that it took up to $8 \mathrm{~h}$ post AuNP or IR treatment for SOD-2 elevation. Therefore, it is likely that the time lag between nanoparticleinduced ROS production (early event $30 \mathrm{~min}-1 \mathrm{~h}$ ) and the cells biological response (elevated SOD-2) is sufficient to allow significant ROS driven damage.

In the clinical context, AuNPs could be directly administered to the tumour bed after lumpectomy or mastectomy, prior to intraoperative radiotherapy. As such we elected to directly inject AuNP-DP to determine if the radiosensitising efficacy identified in vitro translated to the in vivo setting. Landmark studies highlighting the radiosensitisation potential of AuNPs have typically used in vivo dosing in excess of $2 \mathrm{~g} / \mathrm{Kg}$ Au. $(49,50)$ However, due to the higher 
endocytotic potential AuNP-DP was administered at $6 \mathrm{mg} / \mathrm{kg}$. This concentration was based on our previous study using small $(<4 \mathrm{~nm})$ DTDTPA-grafted AuNPs, which exhibited a lower internalisation potential.(24) A pre-determined experimental end-point of tumour volume developing to four times initial treatment volume was applied. Solely using this criteria suggests that AuNP-DP confers no statistically significant $(\mathrm{p}=0.13)$ advantage in terms of tumour growth delay compared to radiation alone, a result mirrored by the Kaplan Meyer survival curve (Figure 7C: IR verses IR + AuNP-DP p=0.081 Mantel-Cox test). This result is strongly influenced by the treatment scheduling. A fixed experimental endpoint fails to account for the pronounced tumour delay observed during the first 12 days post treatment and the data presented in Figure 7D. Extrapolating from the radiation sensitivity data (Figure 5B) at 4 Gy, AuNP-DP generates a dose enhancement factor (DEF) of 3.2, indicating that the combined effect of IR +AuNP-DP treatment is equivalent to an approximate dose of $12 \mathrm{~Gy}$. On the basis that a single 4 Gy fraction resulted in a 3.4 day tumour growth delay compared to the untreated tumours, applying the estimated dose fraction of 12 Gy in the presence of AuNP-DP, a growth delay of 10.2 days should result. This was indeed the observed outcome with a measured combined growth delay of 10.88 days. This encouraging result outlines the potential for AuNPs to prove effective within a specific cohort of tumours that exhibit lower basal ROS scavenging capacity. Furthermore, as the impact of the combined treatment was front loaded post treatment, the full potential of AuNP-DP is yet to be realised through scheduling and radiation dose fractionation studies.

These investigations report the successful synthesis of a novel multifunctional AuNP that demonstrates significant internalisation and radiosensitisation. Furthermore, SOD-2 is identified as a key mediator of inherent radioresistance between cell lines. Importantly, in vitro observations translated to effective tumour growth delay in vivo. Using the example of breast cancer, the significance of the in vivo radiosensitisation should not be underestimated, given the known doubled edged sword effects conferred by a radiotherapy boost for patients with left sided breast cancer.

\section{References}


1. Jain S, Coulter JA, Hounsell AR, Butterworth KT, McMahon SJ, Hyland WB, et al. Cellspecific radiosensitization by gold nanoparticles at megavoltage radiation energies. Int J Radiat Oncol Biol Phys 2011;79(2):531-539.

(2) Miladi I, Alric C, Dufort S, Mowat P, Dutour A, Mandon C, et al. The In Vivo Radiosensitizing Effect of Gold Nanoparticles Based MRI Contrast Agents. Small 2014;10(6):1116-24.

(3) Butterworth KT, McMahon SJ, Currell FJ, Prise KM. Physical basis and biological mechanisms of gold nanoparticle radiosensitization. Nanoscale 2012 4(16):4830-4838.

(4) Yang C, Uertz J, Yohan D, Chithrani BD. Peptide modified gold nanoparticles for improved cellular uptake, nuclear transport, and intracellular retention. Nanoscale 2014 6(20):1202612033.

(5) Chithrani BD, Ghazani AA, Chan WC. Determining the size and shape dependence of gold nanoparticle uptake into mammalian cells. Nano Lett 2006 6(4):662-668.

(6) Yi X, Shi X, Gao H. Cellular uptake of elastic nanoparticles. Phys Rev Lett 2011; 107(9):098101.

(7) Chithrani BD, Chan WC. Elucidating the mechanism of cellular uptake and removal of protein-coated gold nanoparticles of different sizes and shapes. Nano Lett 2007;7(6):15421550.

(8) Taggart LE, McMahon SJ, Currell FJ, Prise KM, Butterworth KT. The role of mitochondrial function in gold nanoparticle mediated radiosensitisation. Cancer Nanotechnol 2014;5(1):5.

(9) Coulter JA, Hyland WB, Nicol J, Currell FJ. Radiosensitising nanoparticles as novel cancer therapeutics--pipe dream or realistic prospect? Clin Oncol 2013; 25(10):593-603.

(10) Lasagna-Reeves C, Gonzalez-Romero D, Barria MA, Olmedo I, Clos A, Sadagopa Ramanujam VM, et al. Bioaccumulation and toxicity of gold nanoparticles after repeated administration in mice. Biochem Biophys Res Commun 2010; 393(4):649-655.

(11) Gref R, Luck M, Quellec P, Marchand M, Dellacherie E, Harnisch S, et al. 'Stealth' coronacore nanoparticles surface modified by polyethylene glycol (PEG): influences of the corona (PEG chain length and surface density) and of the core composition on phagocytic uptake and plasma protein adsorption. Colloids Surf B Biointerfaces 2000; 18(3-4):301-313.

(12) Wang M, Thanou M. Targeting nanoparticles to cancer. Pharmacol Res 2010; 62(2):9099.

(13) Hao Y, Yang X, Song S, Huang M, He C, Cui M, et al. Exploring the cell uptake mechanism of phospholipid and polyethylene glycol coated gold nanoparticles. Nanotechnology 2012; 23(4):045103.

(14) McCaffrey J, McCrudden CM, Ali AA, Massey AS, McBride JW, McCrudden MT, et al. Transcending epithelial and intracellular biological barriers; a prototype DNA delivery device. J Control Release 2016; 226:238-247. 
(15) Liu Y, Shipton MK, Ryan J, Kaufman ED, Franzen S, Feldheim DL. Synthesis, stability, and cellular internalization of gold nanoparticles containing mixed peptide-poly(ethylene glycol) monolayers. Anal Chem 2007; 79(6):2221-2229.

(16) Engel S, Fritz EC, Ravoo BJ. New trends in the functionalization of metallic gold: from organosulfur ligands to N-heterocyclic carbenes. Chem Soc Rev 2017; 46(8):2057-2075.

(17) Midoux P, Kichler A, Boutin V, Maurizot JC, Monsigny M. Membrane permeabilization and efficient gene transfer by a peptide containing several histidines. Bioconjug Chem 1998; 9(2):260-267.

(18) Blanco E, Shen H, Ferrari M. Principles of nanoparticle design for overcoming biological barriers to drug delivery. Nat Biotechnol 2015; 33(9):941-951.

(19) Fernandez-Recio J, Vazquez A, Civera C, Sevilla P, Sancho J. The tryptophan/histidine interaction in alpha-helices. J Mol Biol 1997; 267(1):184-197.

(20) Early Breast Cancer Trialists' Collaborative Group (EBCTCG), Darby S, McGale P, Correa C, Taylor C, Arriagada R, et al. Effect of radiotherapy after breast-conserving surgery on 10-year recurrence and 15-year breast cancer death: meta-analysis of individual patient data for 10,801 women in 17 randomised trials. Lancet 2011; 378(9804):1707-1716.

(21) Bartelink H, Horiot JC, Poortmans PM, Struikmans H, Van den Bogaert W, Fourquet A, et al. Impact of a higher radiation dose on local control and survival in breast-conserving therapy of early breast cancer: 10-year results of the randomized boost versus no boost EORTC 22881-10882 trial. J Clin Oncol 2007; 25(22):3259-3265.

(22) Darby SC, Ewertz M, McGale P, Bennet AM, Blom-Goldman U, Bronnum D, et al. Risk of ischemic heart disease in women after radiotherapy for breast cancer. $N$ Engl J Med 2013; 368(11):987-998.

(23) Cui L, Her S, Dunne M, Borst GR, De Souza R, Bristow RG, et al. Significant Radiation Enhancement Effects by Gold Nanoparticles in Combination with Cisplatin in Triple Negative Breast Cancer Cells and Tumor Xenografts. Radiat Res 2017; 187(2):147-160.

(24) Butterworth KT, Nicol JR, Ghita M, Rosa S, Chaudhary P, McGarry CK, et al. Preclinical evaluation of gold-DTDTPA nanoparticles as theranostic agents in prostate cancer radiotherapy. Nanomedicine (Lond) 2016; 11(16):2035-2047.

(25) Joh DY, Sun L, Stangl M, Al Zaki A, Murty S, Santoiemma PP, et al. Selective targeting of brain tumors with gold nanoparticle-induced radiosensitization. PLoS One 2013; 8(4):e62425.

(26) Hainfeld JF, Dilmanian FA, Zhong Z, Slatkin DN, Kalef-Ezra JA, Smilowitz HM. Gold nanoparticles enhance the radiation therapy of a murine squamous cell carcinoma. Phys Med Biol 2010; 55(11):3045-3059.

(27) Turkevich J, Stevenson PC, Hillier J. A Study of the nucleation and growth processes in the synthesis of colloidal gold. Discuss. faraday Soc 1951; 11:55-75. 
(28) Zhao P, Li N, Astruc D. State of the art in gold nanoparticle synthesis. Coord. Chem. Rev 2013; 257:638-665.

(29) Harrison E, Nicol JR, Macias-Montero M, Burke GA, Coulter JA, Meenan BJ, et al. A comparison of gold nanoparticle surface co-functionalization approaches using Polyethylene Glycol (PEG) and the effect on stability, non-specific protein adsorption and internalization. Mater Sci Eng C Mater Biol Appl 2016; 62:710-718.

(30) Manson J, Kumar D, Meenan BJ, Dixon D. Polyethylene glycol functionalized gold nanoparticles: the influence of capping density on stability in various media. Gold Bulletin 2011;44(2):99-105.

(31) Butterworth KT, Coulter JA, Jain S, Forker J, McMahon SJ, Schettino G, et al. Evaluation of cytotoxicity and radiation enhancement using $1.9 \mathrm{~nm}$ gold particles: potential application for cancer therapy. Nanotechnology 2010; 21(29):295101.

(32) Coulter JA, Jain S, Butterworth KT, Taggart LE, Dickson GR, McMahon SJ, et al. Cell type-dependent uptake, localization, and cytotoxicity of $1.9 \mathrm{~nm}$ gold nanoparticles. Int $J$ Nanomedicine 2012;7:2673-2685.

(33) Harrison E, Hamilton JWJ, Macias-Montero M, Dixon D. Peptide functionalized gold nanoparticles: the influence of $\mathrm{pH}$ on binding efficiency. Nanotechnology 2017; 28(29):295602.

(34) Shi W, Sahoo Y, Swihart MT. Gold nanoparticles surface-terminated with bifunctional ligands. Colloids Surf A Physicochem Eng Asp 2004; 246(1):109-113.

(35) Park JW, Shumaker-Parry JS. Structural study of citrate layers on gold nanoparticles: role of intermolecular interactions in stabilizing nanoparticles. J Am Chem Soc. 2014;136(5):190721.

(36) Barth A. Infrared spectroscopy of proteins. Biochim Biophys Acta. 2007; 1767(9):1073101.

(37) Liu T, Thierry B. A solution to the PEG dilemma: efficient bioconjugation of large gold nanoparticles for biodiagnostic applications using mixed layers. Langmuir 2012; 28(44):15634-15642.

(38) Wang YH, Chen SP, Liao AH, Yang YC, Lee CR, Wu CH, et al. Synergistic delivery of gold nanorods using multifunctional microbubbles for enhanced plasmonic photothermal therapy. Sci Rep 2014; 4:5685.

(39) Nicol JR, Dixon D, Coulter JA. Gold nanoparticle surface functionalization: a necessary requirement in the development of novel nanotherapeutics. Nanomedicine (Lond) 2015;10(8):1315-1326.

(40) Okita,K., Teramoto,K., Kawahara,H., Fujita,H. Light scattering and refractometry of a monodisperse polymer in binary mixed solvents. J. Phys. Chem. 1968;72(1):278-285. 
(41) Terry CA, Fernandez MJ, Gude L, Lorente A, Grant KB. Physiologically relevant concentrations of $\mathrm{NaCl}$ and $\mathrm{KCl}$ increase DNA photocleavage by an $\mathrm{N}$-substituted 9aminomethylanthracene dye. Biochemistry 2011; 50(47):10375-10389.

(42) Kumar D, Meenan BJ, Dixon D. Glutathione-mediated release of Bodipy(R) from PEG cofunctionalized gold nanoparticles. Int J Nanomedicine 2012; 7:4007-4022.

(43) Schuemann J, Berbeco R, Chithrani DB, Cho SH, Kumar R, McMahon SJ, et al. Roadmap to Clinical Use of Gold Nanoparticles for Radiation Sensitization. Int J Radiat Oncol Biol Phys 2016; 94(1):189-205.

(44) Ray KJ, Sibson NR, Kiltie AE. Treatment of Breast and Prostate Cancer by Hypofractionated Radiotherapy: Potential Risks and Benefits. Clin Oncol (R Coll Radiol) 2015; 27(7):420-426.

(45) Redon CE, Dickey JS, Bonner WM, Sedelnikova OA. gamma-H2AX as a biomarker of DNA damage induced by ionizing radiation in human peripheral blood lymphocytes and artificial skin. Adv Space Res 2009; 43(8):1171-1178.

(46) Lobrich M, Shibata A, Beucher A, Fisher A, Ensminger M, Goodarzi AA, et al. gammaH2AX foci analysis for monitoring DNA double-strand break repair: strengths, limitations and optimization. Cell Cycle 2010; 9(4):662-669.

(47) Huotari J, Helenius A. Endosome maturation. EMBO J 2011; 30(17):3481-3500.

(48) McMahon SJ, Hyland WB, Muir MF, Coulter JA, Jain S, Butterworth KT, et al. Nanodosimetric effects of gold nanoparticles in megavoltage radiation therapy. Radiother Oncol 2011; 100(3):412-416.

(49) Hainfeld JF, Slatkin DN, Smilowitz HM. The use of gold nanoparticles to enhance radiotherapy in mice. Phys Med Biol 2004; 49(18):309-315.

(50) Hainfeld JF, Smilowitz HM, O'Connor MJ, Dilmanian FA, Slatkin DN. Gold nanoparticle imaging and radiotherapy of brain tumors in mice. Nanomedicine (Lond) 2013; 8(10):16011609.

Figure 1 - AuNP physical characterization. A) Hydrodynamic size and B) zeta potential of the various AuNP preparations. C) UV/Vis spectra of the AuNP preparations D) FTIR spectra of free peptide compared against AuNP-P and AuNP-DP indicating successful conjugation.

Figure 2 - A) Stability of nanoparticles over time in $1 \mathrm{M} \mathrm{NaCl}$. Experimental replicates were sampled from multiple batches $(n=4)$. B) Stability of AuNP preparations, assessed by change in size following incubation in foetal calf serum $(10 \%$ or $40 \%)(n=3)$. 
Figure 3 - AuNP internalisation and cytotoxicity. A) - Uptake data quantified using ICPAAS and normalised against AuNP-P $(\mathrm{n}=5)$. B) WST-1 assay indicates minimal cytotoxicity following a $24 \mathrm{~h}$ incubation with AuNPs at $25 \mu \mathrm{g} / \mathrm{ml}$. C \& D) - Dose dependant cytotoxicity of AuNP-DP in cancer cell lines MDA-MB-231 (C) and MCF-7 (D) (n=3). Statistical analysis was performed using a one-way ANOVA with Bonferroni-correction.

Figure 4 - CytoViva imaging of AuNP-DP in breast cells. Enhanced darkfield images (A,C \& E) show cells co-stained with DAPI. Clusters of AuNP-DP appear as bright regions due to their high cross-scattering. Spectral angle mapping (B, D \& F) paints AuNP-DP containing pixels red confirming AuNP uptake. Enhanced darkfield were acquired using a x100 objective, with HSI digitally focused on the central field of view.

Figure 5 - In vitro radiosensitisation of AuNP-DP. Clonogenic survival assays of AuNP-DP in (A) MCF-10A, (B) MDA-MB-231 and (C) MCF-7 cells following incubation at $25 \mu \mathrm{g} / \mathrm{ml}$ for $24 \mathrm{~h}$. Annotated sensitizer enhancement ratios (SER) were calculated using the mean inactivation method and compared against IR alone $(n=3)$. Statistical significance determined by two-way ANOVA.

Figure 6 - AuNP induced oxidative stress. A) DNA double strand breaks were quantified by scoring $\gamma \mathrm{H} 2 \mathrm{aX}$ foci following a 1 Gy dose. $\mathrm{B} \& \mathrm{C})$ - ROS quantified using the fluorescent dye DCFDA over time following IR (2 Gy) alone or AuNP-DP plus IR in (B) MDA-MB-231 and (C) MCF-7 cells. D-F) Western blotting for SOD-2 in cancer cell lines, show the basal level and AuNP induced expression in (D\&E) MDA-MB-231 and (D\&F) MCF-7 cells. G-I) MDA-MB-231 cells were selected due to the SOD-2 induced response and probed to establish time $(\mathrm{G} \& \mathrm{H})$ and radiation $(2 \mathrm{~Gy} ; \mathrm{G} \& \mathrm{I})$ dependent effects. Data represent the mean of three independent experiments. Statistical analysis was performed using a one-way ANOVA with Bonferroni-correction.

Figure 7 - Xenograft tumour delay model with AuNP-DP. Animals were randomly allocated into four treatment groups: untreated $(n=6)$, AuNP-DP only $(n=5)$, IR only (4 Gy; $\mathrm{n}=5$ ) and AuNP-DP + IR (4 Gy; n=6). A) - Mean animal weights. B) Mean tumour growth characteristics of the four treatment groups until the experimental endpoint of $400 \mathrm{~mm}$. B) Kaplan Meyer survival curve based on tumour growth to experimental endpoint. Statistical 
analysis determined using the log-rank test. D) Treatment efficacy defined by the delay in time taken for tumours to develop to $300 \mathrm{~mm}^{3}$. Statistical analysis was performed using a one-way ANOVA with Bonferroni-correction. 
Figure 1

A

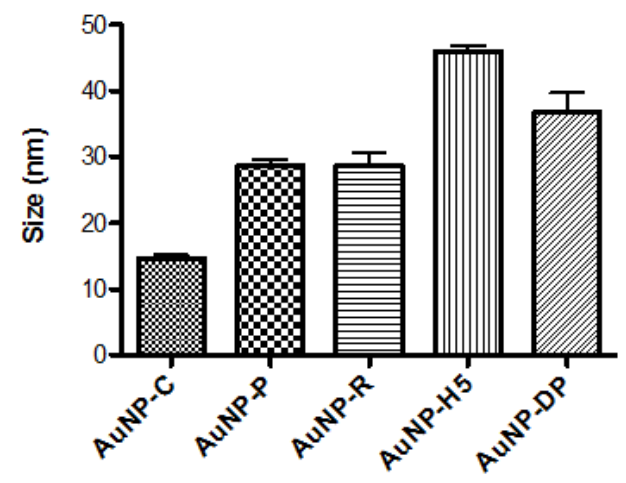

C



B
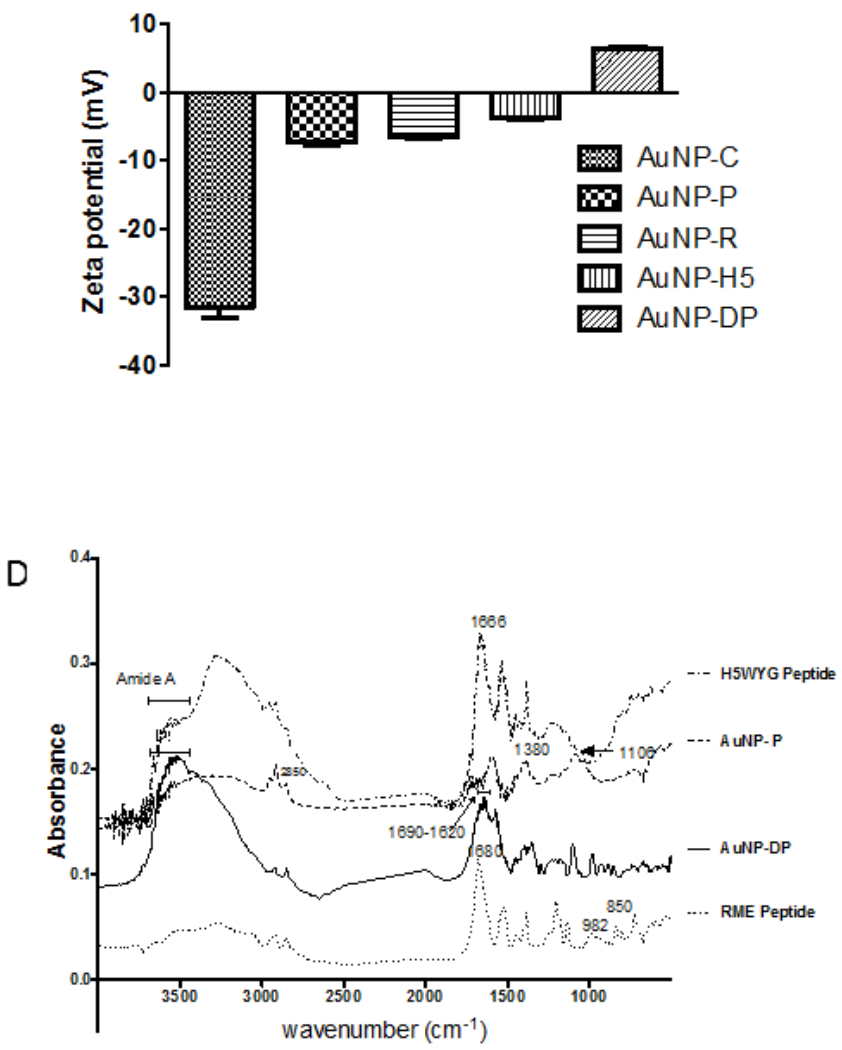
Figure 2

A

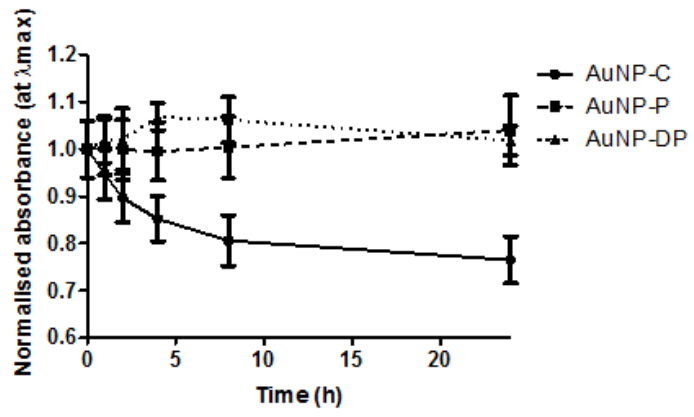

B

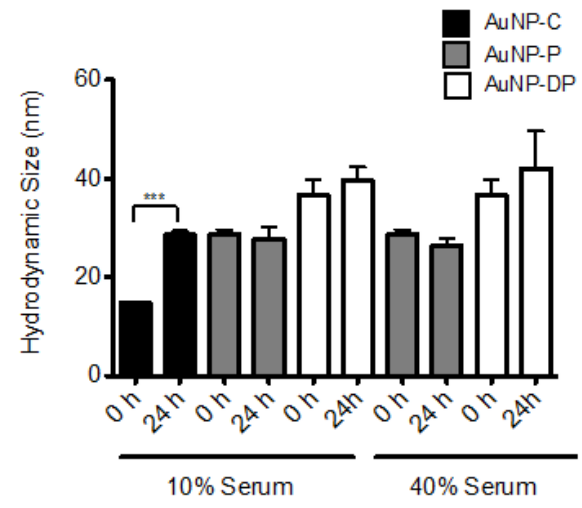


Figure 3

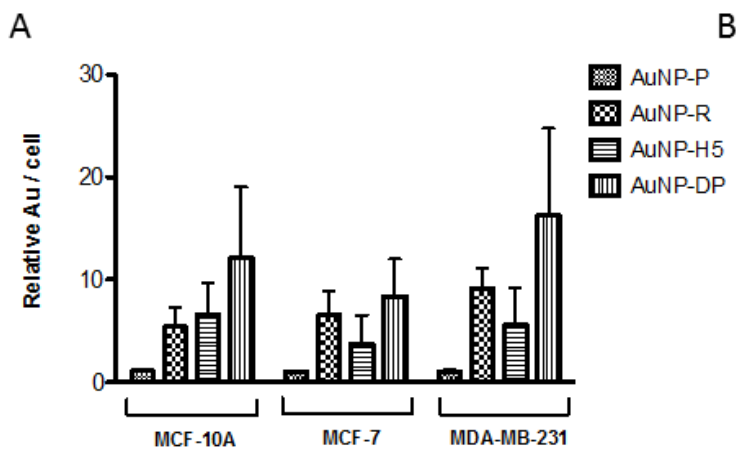

B
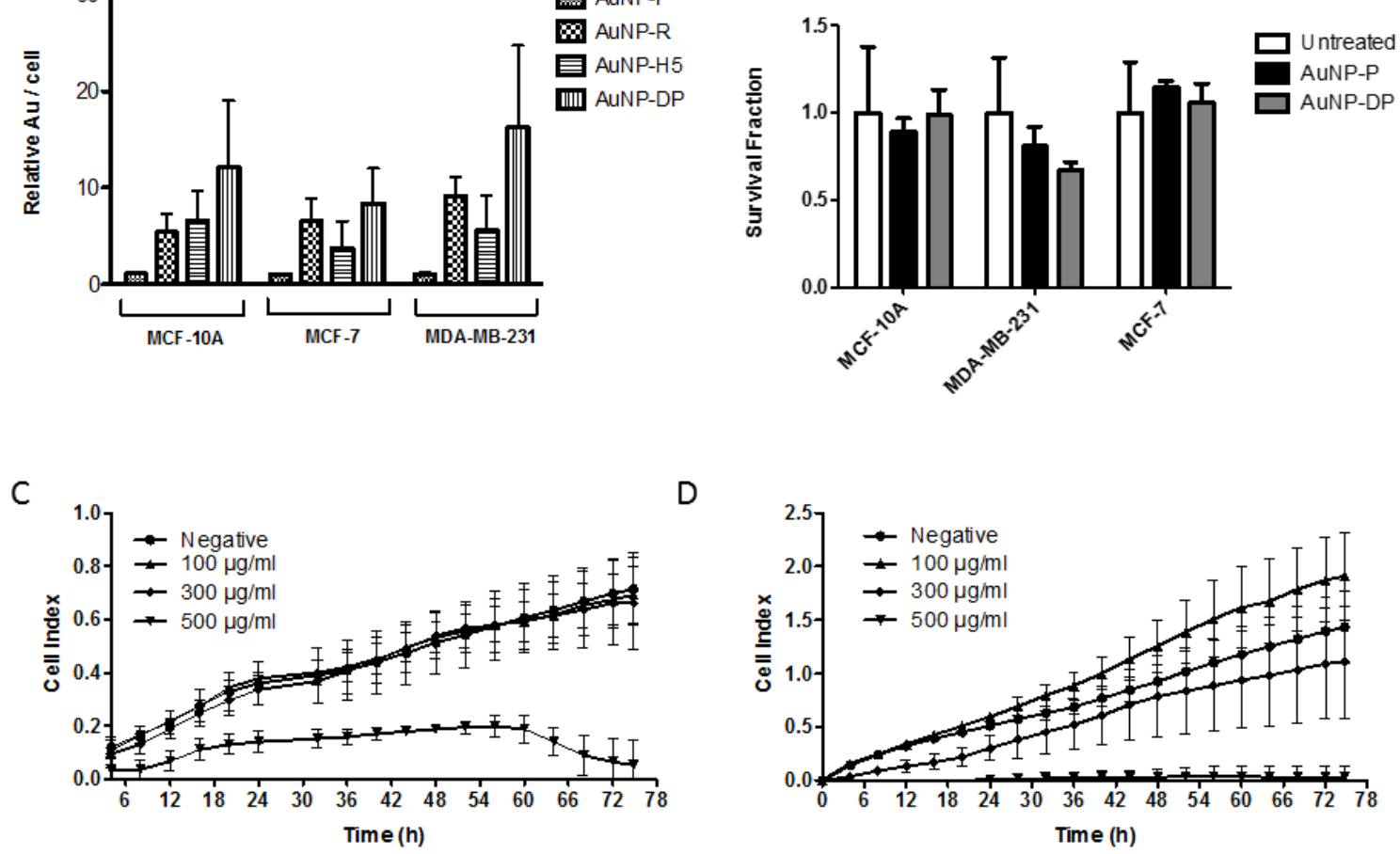
Figure 4

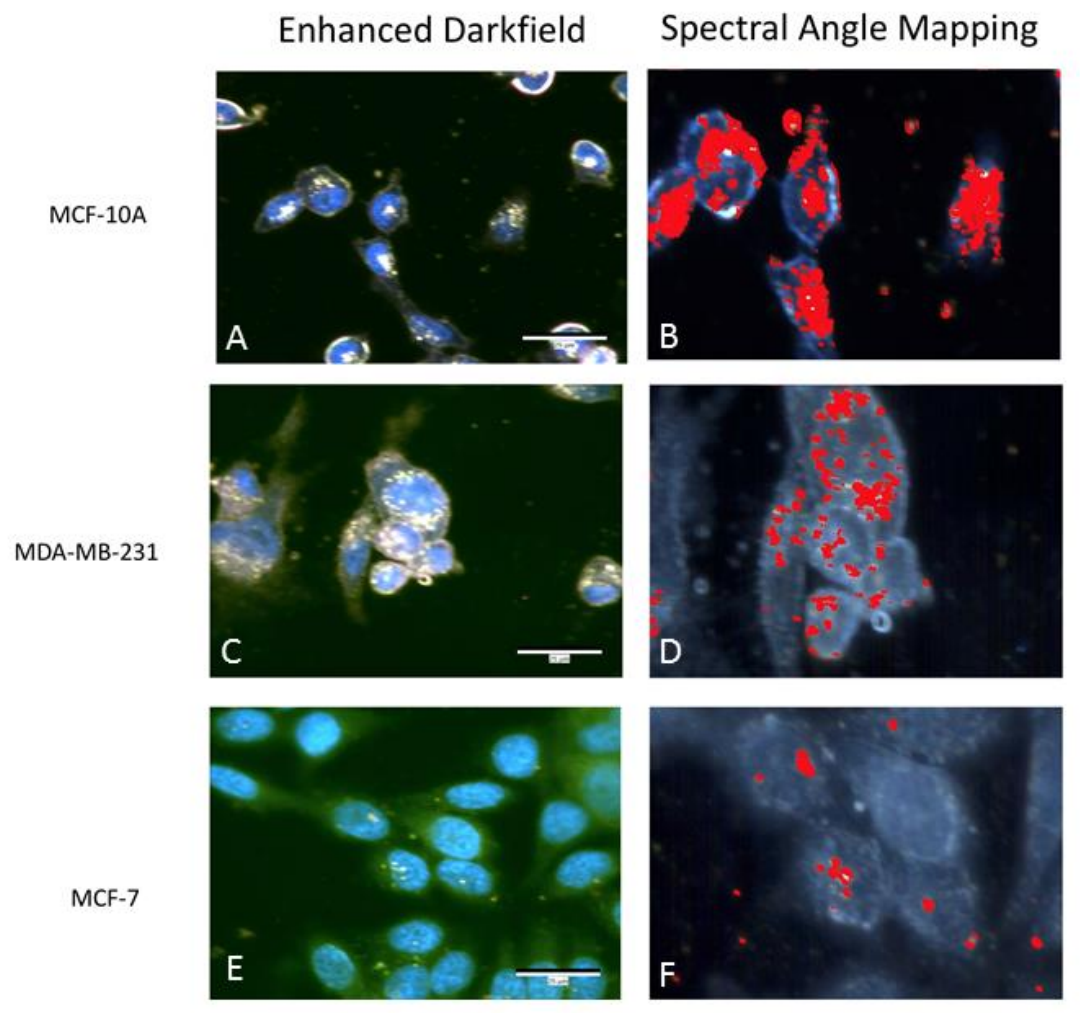


Figure 5

A

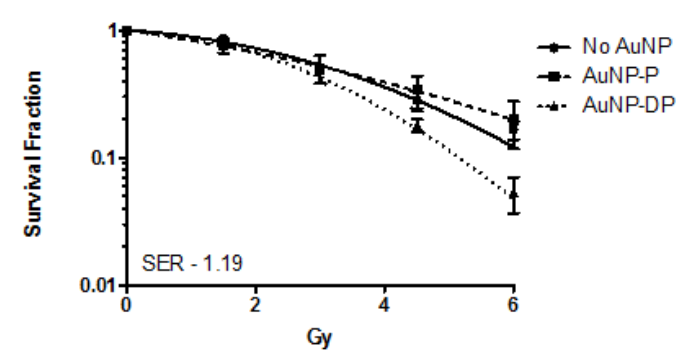

B

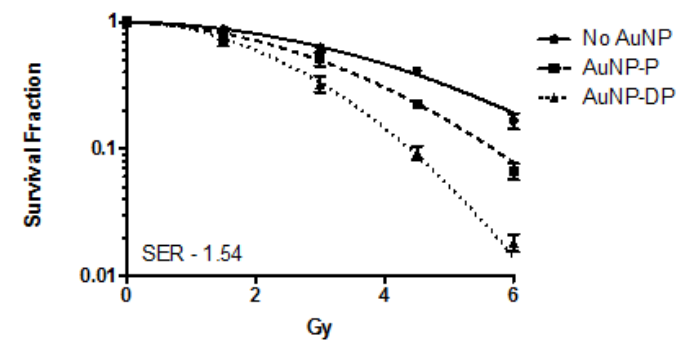

C

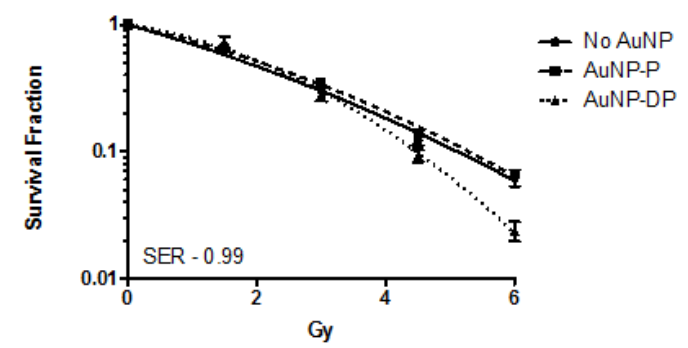


Figure 6
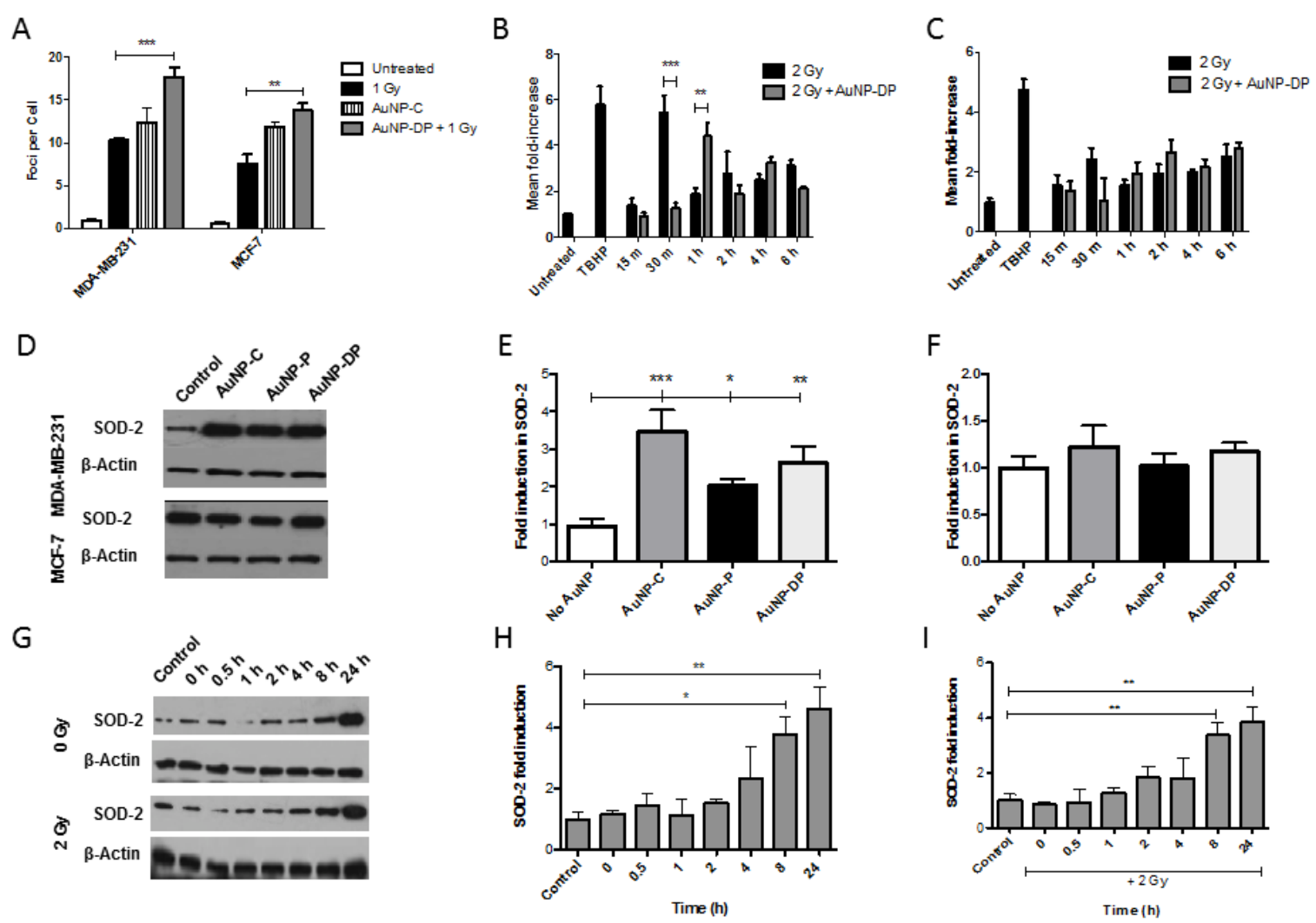
Figure 7

A

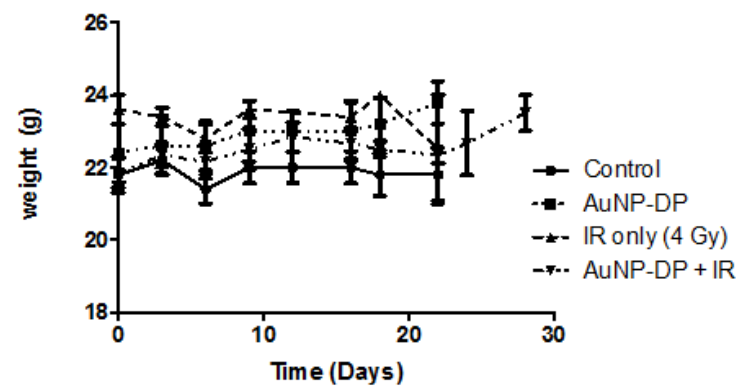

C

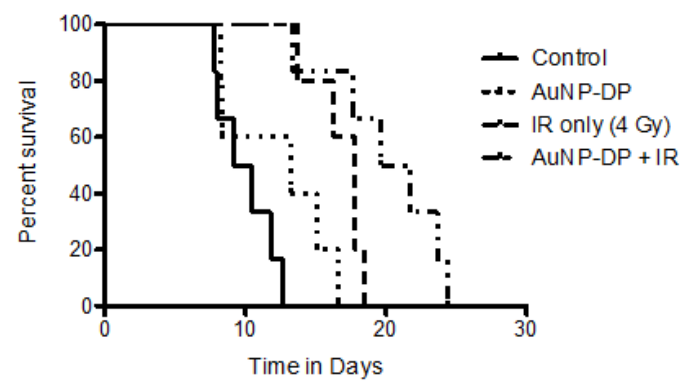

B

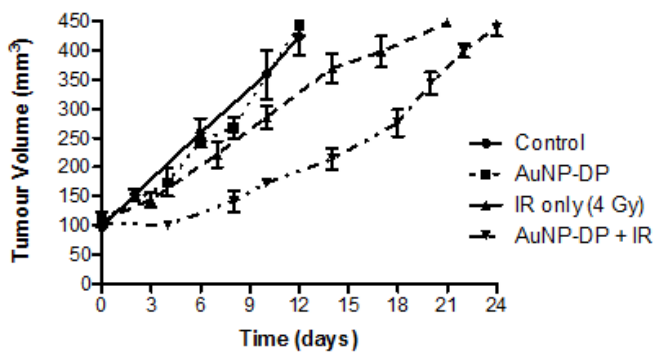

D

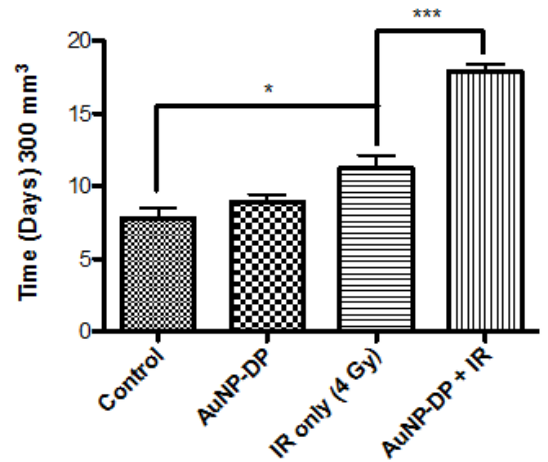


Supplementary Figure 1

S.1
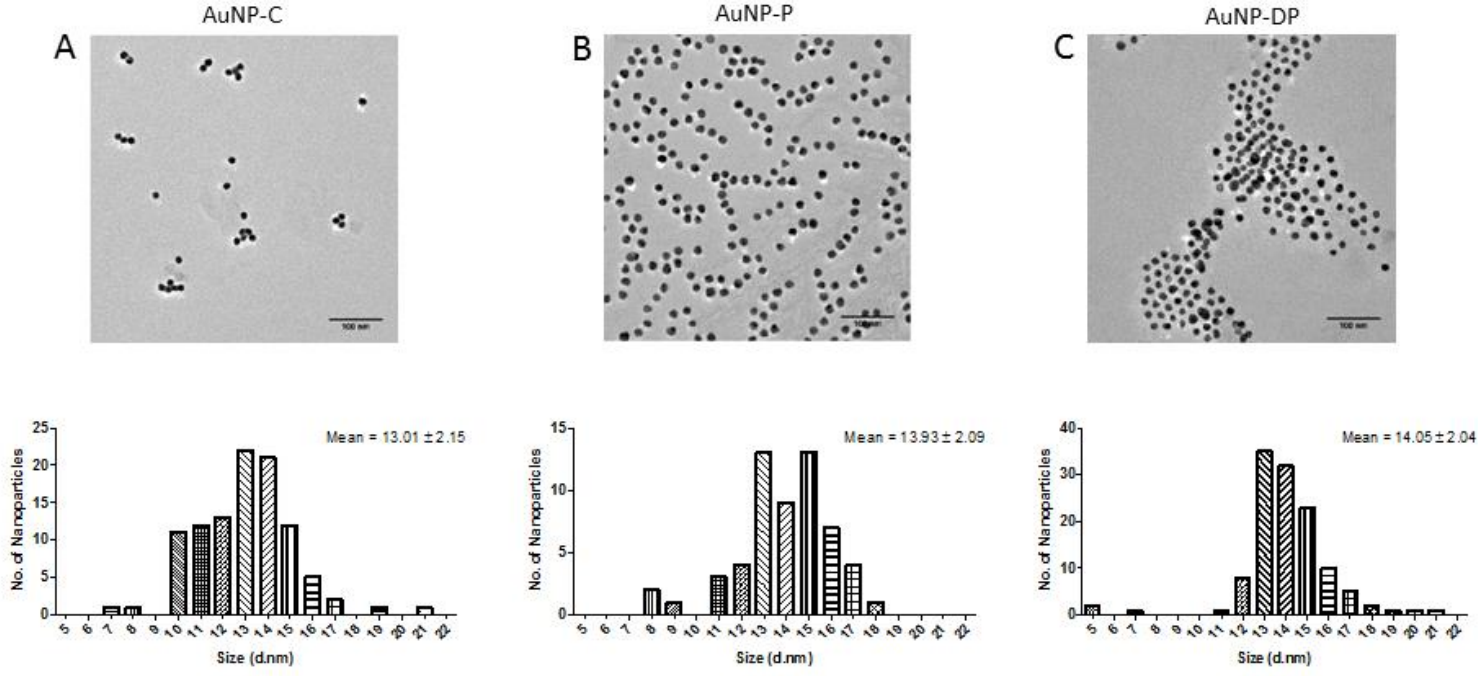
Supplementary Figure 2

S. 2

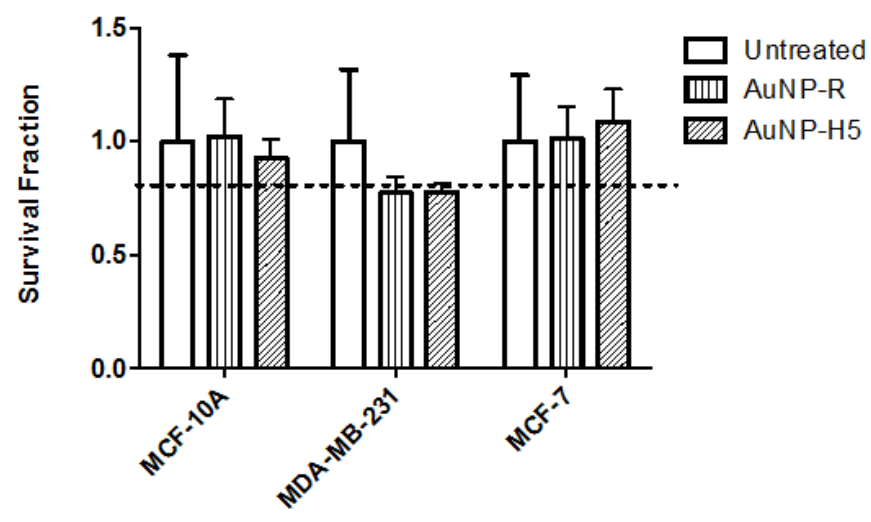


Supplementary Figure 3

A



B

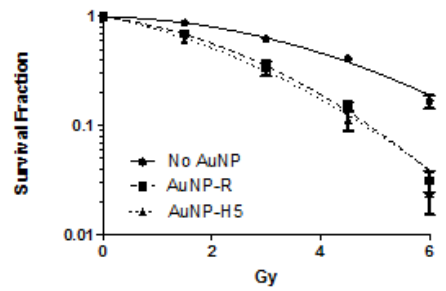

C

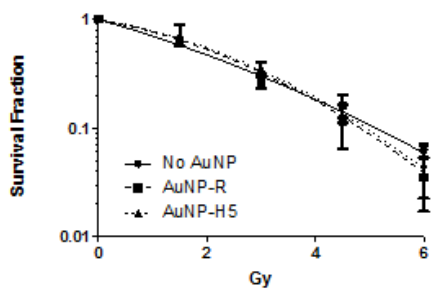

